\title{
Modeling performance of industrial park wastewater treatment plant by STOAT software
}

\author{
Putri Ghina O. Minhaj ${ }^{1}$, Mochammad Adhiraga Pratama ${ }^{1}$, Sandyanto Adityosulindro ${ }^{1 *}$, and Djoko M. \\ Hartono $^{1}$ \\ ${ }^{1}$ Environmental Engineering Study Program, Department of Civil Engineering, Universitas Indonesia, \\ Depok, 16424, Indonesia
}

\begin{abstract}
To control environmental pollution, the Wastewater Treatment Plant (WWTP) plays a vital role in treating wastewater to comply with quality standards before being discharged into the environment. However, not all WWTPs have worked optimally, so the periodic evaluations must be carried out to determine problems and what efforts can be made to improve WWTP processing quality. This study aims to evaluate the Jababeka 1 WWTP, which functions to treat wastewater in Industrial Area 1 and Industrial Area 7, which are in the Jababeka Industrial Estate (KIJ). Evaluation is carried out by comparing the actual processing efficiency with the related literature. Evaluation is also carried out by simulating the process and operation of WWTP using STOAT software. STOAT is one of the WWTP system modeling software mostly used to predict the wastewater treatment plant's performance. The test results show that for the efficiency of Jababeka 1, WWTP removal for parameters BOD, COD, and TSS are 90\%, 93.02\%, and 96.12\%. Based on the data obtained, modeling based on sensitivity analysis was also carried out using STOAT software to determine the most significant WWTP performance parameters. It was found that the wastewater discharge was the most critical parameter affecting the removal efficiency of TSS and BOD.
\end{abstract}

\section{Introduction}

According to the 2018 Environmental Statistics data, all rivers in Indonesia are polluted in light, moderate, and heavily polluted based on the criteria for river water quality in Government Regulation Number 82 of 2001 concerning Water Quality Management and Water Pollution Control with class II category [1]. The Wastewater Treatment Plant or WWTP is a facility with a combination of processing units (mechanical, physical, chemical, and biological) used to remove pollutants in wastewater to meet applicable regulatory quality standards [2].

However, achieving the quality of effluent that is following regulations is also challenging. Various problems faced by WWTP operators such as (i) Inappropriate design of

\footnotetext{
* Corresponding author: adityosulindro@eng.ui.ac.id
} 
hydraulic and mass loading [3] (ii) mechanical equipment problems, and (iii) low operation, maintenance, and troubleshooting can cause poor removal efficiency. Besides, the deterioration of wastewater quality due to population growth and land-use changes are also essential to be considered [4].

Therefore, WWTP operators need to understand their WWTP's behavior, especially when facing fluctuations in the quality and quantity of wastewater input. Nowadays, WWTP behavior can be modeled and predicted by computer software. STOAT (Sewage Treatment Operation and Analysis over Time) is an example of a free wastewater treatment system modeling software. Using STOAT, users can design a wastewater treatment plant system, determine how each unit is connected and operated, and predict the wastewater treatment plant's performance in a specified time [5].

This study aims to evaluate the removal efficiency and the operating parameters of Jababeka 1 WWTP. STOAT evaluated operating parameters. This study was conducted at the Jababeka 1 WWTP located in the Jababeka Industrial Estate, Cikarang, Bekasi, West Java. This WWTP was chosen as the case study considering its enormous capacity (up to $18,000 \mathrm{~m}^{3} /$ day) and its indispensable role in Jababeka Industrial Park.

\section{Method}

\subsection{Case study}

PT. Jababeka Tbk was founded in 1989 and is the first genuine industrial estate development company in Indonesia. The Jababeka Industrial Estate has been equipped with a clean water supply system and a wastewater treatment system, consisting of two installations. In addition to treating wastewater originating from industrial activities, the Jababeka WWTP also treats wastewater from residential and commercial areas. The Jababeka 1 WWTP is a WWTP designed to serve two industrial areas, namely the Jababeka Phase/Zone 1 and the Jababeka Phase/Zone 2. There are around 1,100 industries that are included in the service sector and consist of industries engaged in food and beverage (non-alcoholic), electronics and automotive components, textiles, garments, and laundry, glass, plastics, dolls, chemicals (paints, chemicals) additives, detergents, soaps, shampoos, and cosmetics). Until now, the Jababeka 1 WWTP has an actual wastewater capacity of $12,431 \mathrm{~m}^{3} /$ day, while its design capacity is $18,000 \mathrm{~m}^{3} /$ day.

\subsection{Sampling protocols}

Sampling is carried out at three points, namely before the bar screen unit where the wastewater is still raw wastewater, after the primary clarifier unit, which is the point after preliminary processing where the parameter removal efficiency is quite large, and after the secondary clarifier unit or before the wastewater has been treated before discharged into the receiving water body. The three points were chosen because they describe the condition of the influent wastewater that has not undergone a treatment process, in the condition that the wastewater has passed the preliminary treatment stage. In the instant, the wastewater is discharged into the water body or commonly referred to as effluent wastewater which aims to determine the quality of wastewater after through the WWTP processing. 


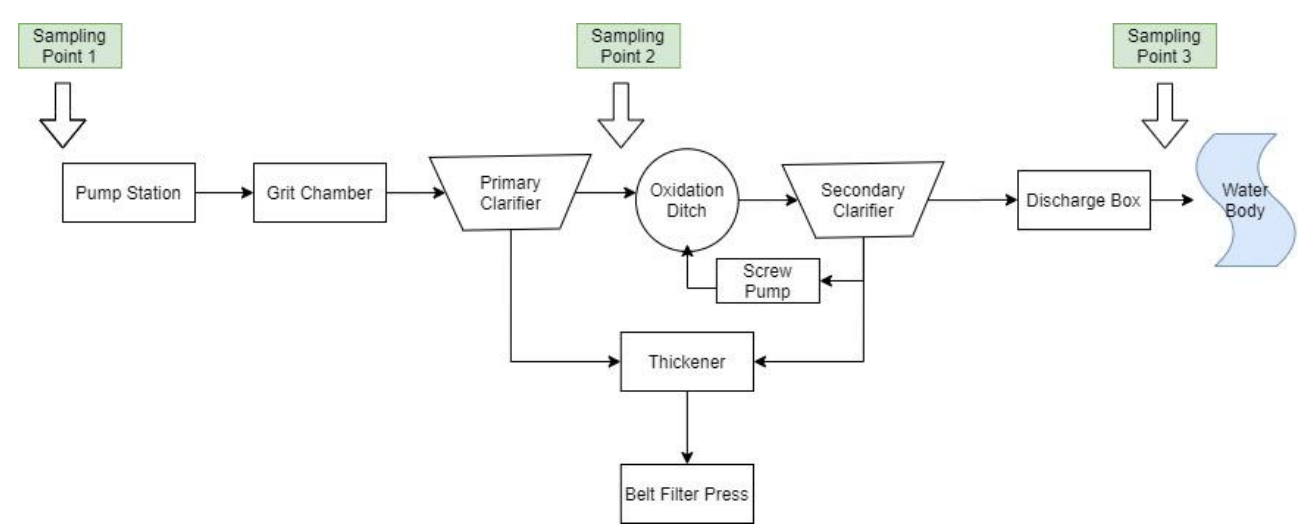

Fig 1. Sampling Points. (Source: Author's Analysis, 2020)

Sampling was carried out at three points to determine the efficiency of the separation of each processing unit and the WWTP as a whole. Sampling was carried out on a composite basis where the sampling was carried out three times each, which was adjusted to the hydraulic retention time with the interval for each sampling being 4 hours. Sampling was carried out at three different points: the influent of wastewater treatment, the effluent of the pre-treatment unit, and the effluent of wastewater before being discharged into the water body. As for the parameters to be tested in this sampling are BOD, COD, and TSS.

\subsection{Analytical methods}

Biological Oxygen Demand (BOD), Chemical Oxygen Demand (COD), and Total Suspended Solid (TSS) analysis were carried out in the wastewater samples. According to the Indonesian National Standard (SNI), the test is carried out by the method, namely SNI 6989.72: 2009, SNI 6989.2: 2009, and SNI 06-6989.3-2004.

\subsection{Data analysis}

\subsubsection{Removal efficiency}

After knowing the value of each parameter at each sampling point, the value of the allowance efficiency is calculated by the processing unit using the following formula

$$
E=\frac{C_{i}-C_{e}}{C_{i}} x 100
$$

Where $\mathrm{E}$ is the removal efficiency, $\mathrm{Ci}$ is the influent concentration $(\mathrm{mg} / \mathrm{L})$, and $\mathrm{Ce}$ is the effluent concentration $(\mathrm{mg} / \mathrm{L})$.

\subsubsection{Modelling using STOAT software}

\subsubsection{Sensitivity analysis}


Sensitivity analysis is a study conducted to measure the impact of fluctuations in the parameters of a mathematical model or the system's performance by dividing the uncertainty of the output of the simulation model by its input [6]. In modeling using STOAT, the value of sensitivity analysis or sensitivity index must be considered. This value will determine which parameters the changes will significantly affect the results of the modeling performed. The formula or equation used to calculate the sensitivity index is as follows.

$$
\text { Sensitivity Index }(S I)=\frac{\left[\frac{O^{\prime}-O}{O}\right]}{\left[\frac{P^{\prime}-P}{P}\right]}
$$

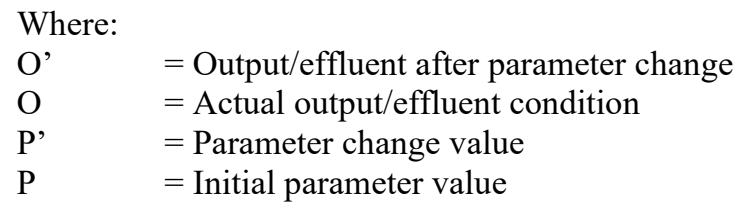

To find out how much effect the parameter change from the sensitivity index value can be seen in the following table.

Table 1. Sensitivity Value Depiction

\begin{tabular}{|c|c|c|}
\hline Sensitivity Level & Sensitivity Range & Sensitivity \\
\hline I & $0 \leq\left|S_{i}\right| \leq 0.05$ & Insensitive \\
\hline II & $0.05 \leq\left|S_{i}\right| \leq 0.2$ & Weak Sensitive \\
\hline III & $0.2 \leq\left|S_{i}\right| \leq 1$ & Sensitive \\
\hline IV & $\left|S_{i}\right|>1$ & Highly Sensitive \\
\hline
\end{tabular}

Source: [7]

\subsubsection{Long-Term Projection}

The purpose of conducting simulation using STOAT is to determine which parameters have the most influence on changes in the effluent quality of the wastewater produced and make long-term predictions of the ability of WWTP to treat wastewater. To make long-term predictions for WWTP, a linear value equation of the wastewater discharge is needed from the existing wastewater discharge graph (2019) for WWTP. From this linear equation, the long-term predictive discharge values in this study will be obtained for 5 and 10 years, then used in STOAT modeling.

\section{Results and discussion}

\subsection{WWTP efficiency}


Based on Table 2, it can be seen that overall the Jababeka 1 WWTP has an efficiency value of above $90 \%$, and the quality of the effluent has met the established quality standards, which means that the effluent of the Jababeka 1 WWTP has met the requirements and is safe to dispose of into water bodies. However, when compared with the standard efficiency that should be owned by WWTP, Jababeka 1 WWTP has just met the efficiency value for COD parameters of $93 \%$. In contrast, for the other two parameters, the new BOD has an allowance efficiency of $90 \%$ from $96.6 \%$ and a TSS parameter of $96.12 \%$ of $98 \%$.

Table 2. WWTP Efficiency

\begin{tabular}{|c|c|c|c|}
\hline Parameter & $\begin{array}{c}\text { WWTP } \\
\text { Influent } \\
(\mathbf{m g} / \mathbf{L})\end{array}$ & $\begin{array}{c}\text { WWTP } \\
\text { Effluent } \\
\text { (mg/L) }\end{array}$ & $\begin{array}{c}\text { Efficiency } \\
(\%)\end{array}$ \\
\hline TSS & 206 & 8 & 96.12 \\
\hline BOD & 153.55 & 15.35 & 90 \\
\hline COD & 888 & 62 & 93.02 \\
\hline
\end{tabular}

Source: Author's Analysis, 2020

\subsection{Variation in Inflow and organic loading}

Wastewater that enters the Jababeka 1 WWTP has a wildly fluctuating quantity and quality. Based on Jababeka 1 WWTP data, in 2019, the average discharge value of incoming and treated wastewater was $12,431.9 \mathrm{~m}^{3} /$ day, while the maximum discharge value was 19,023 $\mathrm{m}^{3} /$ day and the minimum discharge value was $4,629 \mathrm{~m}^{3} /$ day. Whereas in 2020 to March, the average discharge, maximum, and minimum discharge values that entered the Jababeka 1 WWTP were $13,453.6 \mathrm{~m}^{3} /$ day, $16,977 \mathrm{~m}^{3} /$ day, and $6,230 \mathrm{~m}^{3} /$ day, respectively.

Apart from the fluctuating quantity of wastewater, the quality of wastewater that enters the Jababeka 1 WWTP also seems to fluctuate. Based on the data owned by Jababeka 1 WWTP, for COD parameters in wastewater in 2019 it has an average value of $1,080 \mathrm{mg} / \mathrm{L}$, a maximum value of $6,165 \mathrm{mg} / \mathrm{L}$, and a minimum value of $135 \mathrm{mg} / \mathrm{L}$, while for parameters BOD in wastewater in 2019 it has an average value of $390 \mathrm{mg} / \mathrm{L}$, a maximum value of 1,022 $\mathrm{mg} / \mathrm{L}$ and a minimum value of $106 \mathrm{mg} / \mathrm{L}$. There are fluctuations in both the quantity and quality of wastewater due to factory activities, and production rates which are strongly influenced by certain celebrations or holiday periods.

\subsection{Model select}

The units used in STOAT were adjusted to the units in the field, namely the Grit Chamber, Primary Clarifier, Oxidation Ditch, and Secondary Settling Tank, as well as the number and dimensions of each unit. For the Grit Chamber, four units with a volume of $18.15 \mathrm{~m}^{3}$ each, one primary clarifier unit volume of $4,137.42 \mathrm{~m}^{3}$, four oxidation ditch units with a volume of $3,400 \mathrm{~m}^{3}$, and two secondary clarifier units with a surface area of $611.6 \mathrm{~m}^{2}$. The secondary clarifier unit's return sludge will be pumped back into the inlet oxidation ditch and mix with the existing influent. 


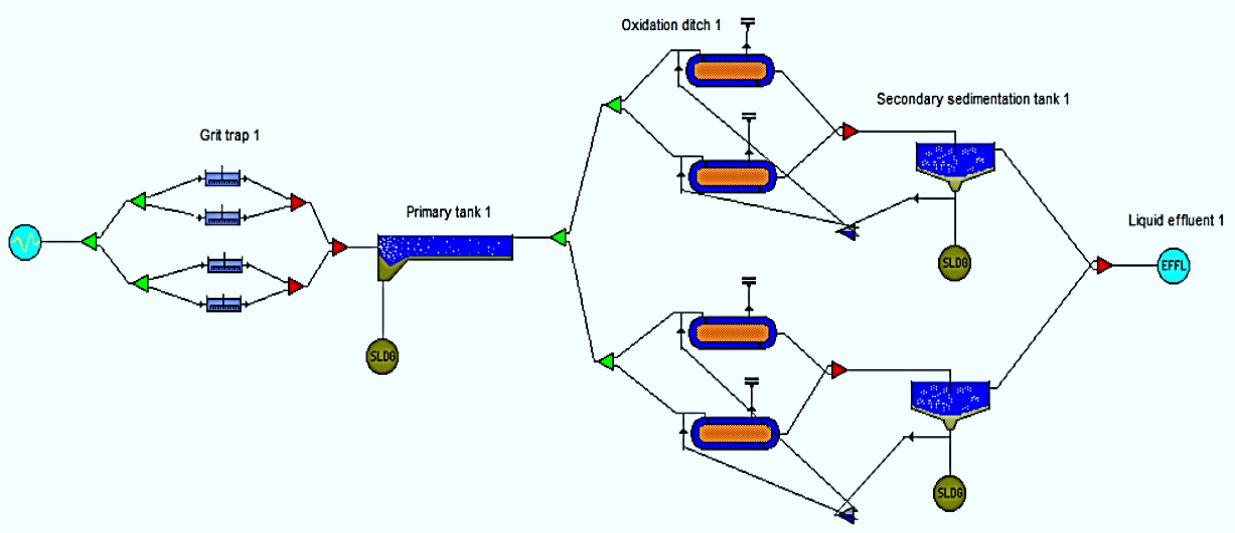

Fig 2. WWTP System Modelling with STOAT (Source: Author's Analysis, 2020)

Modeling is done using the BOD model. The primary clarifier unit is modeled in several well-mixed tank series. Each tank has the same volume and settling area and is assumed to operate at a constant volume. Some of the data components required in this modeling include Particulate BOD, Volatile and Non-volatile Solid, divided into settleable and non-settleable fractions. Later, the model will assume that the settleable and non-settleable ratio in the incoming wastewater is fixed. For the Oxidation Ditch unit, the model used to process activated sludge or activated sludge in this study is Activated Sludge Model 1 (ASAL 1). This model consists of various differential equations written as mass balance.

Some of the differences between the STOAT model and the conditions in the field is the condition of the model, which assumes that the WWTP has just started working, so it will take time to adjust until the processing results are steady state while the WWTP in the field has been running for years so that the effluent results obtained are already is the result of processing in a steady state. Therefore, before starting the simulation process, it is necessary to validate the model to ensure that the conditions and effluents produced by the STOAT model are the same as the conditions and effluents in the field. The influent data used in STOAT modeling is data obtained through measurement results and sample testing. For simulation and sensitivity analysis, the unit used remains the same, but there are modifications to the discharge value, load parameters, and operation and process parameters used.

Table 3. Influent Pattern Modelling of Jababeka 1 WWTP

\begin{tabular}{|c|c|c|}
\hline Parameter & Value & Source \\
\hline Discharge & $12,431 \mathrm{~m}^{3} /$ day & Sampling and Interview \\
\hline Soluble BOD & $75 \mathrm{mg} / \mathrm{L}$ & Sampling and Interview \\
\hline Particulate BOD & $75 \mathrm{mg} / \mathrm{L}$ & Sampling and Interview \\
\hline Volatile Solid & $154.5 \mathrm{mg} / \mathrm{L}$ & Sampling and Interview \\
\hline Non Volatile Solid & $51.5 \mathrm{mg} / \mathrm{L}$ & Sampling and Interview \\
\hline
\end{tabular}




\begin{tabular}{|l|l|l|}
\hline Dissolved Oxygen & $2 \mathrm{mg} / \mathrm{L}$ & STOAT Default \\
\hline
\end{tabular}

Source: Author's Analysis, 2020

Wastewater influent data used in BOD modeling is adjusted from the state of effluent wastewater in the field both from the discharge value, BOD, and Volatile Solid value. The discharge value itself is obtained from measuring the average wastewater discharge for Jababeka 1 WWTP throughout 2019, while the BOD and Volatile Solid values come from testing the wastewater samples carried out during the study.

Table 4. Initial Data Primary Clarifier Unit Modelling Jababeka 1 WWTP

\begin{tabular}{|c|c|c|}
\hline Parameter & Value & Source \\
\hline Soluble BOD & $75 \mathrm{mg} / \mathrm{L}$ & Sampling and Interview \\
\hline Dissolved Oxygen & $2 \mathrm{mg} / \mathrm{L}$ & STOAT Default \\
\hline Particulate BOD & $75 \mathrm{mg} / \mathrm{L}$ & Sampling and Interview \\
\hline $\begin{array}{c}\text { Settleable Volatile } \\
\text { Solid }\end{array}$ & $120.51 \mathrm{mg} / \mathrm{L}$ & Sampling and Interview \\
\hline $\begin{array}{c}\text { Non-Settleable } \\
\text { Volatile Solid }\end{array}$ & $34 \mathrm{mg} / \mathrm{L}$ & Sampling and Interview \\
\hline $\begin{array}{c}\text { Settleable Non- } \\
\text { Volatile Solid }\end{array}$ & $34.35 \mathrm{mg} / \mathrm{L}$ & Sampling and Interview \\
\hline $\begin{array}{c}\text { Non-Settleable Non- } \\
\text { Volatile Solid }\end{array}$ & $17.15 \mathrm{mg} / \mathrm{L}$ & Sampling and Interview \\
\hline
\end{tabular}

Source: Author's Analysis, 2020

Just like the wastewater influent data presented in Table 3, in Table 4, the BOD and Volatile Solid values also come from the results of sample measurements taken during the study, while for other data such as the Dissolved Oxygen value using the default from STOAT in the form of the average value of the oxygen content on wastewater.

Table 5. Initial Data Unit Oxidation Ditch

\begin{tabular}{|c|c|c|}
\hline Parameter & Value & Source \\
\hline Soluble BOD & $5 \mathrm{mg} / \mathrm{L}$ & STOAT Default \\
\hline MLSS & $3,000 \mathrm{mg} / \mathrm{L}$ & STOAT Default \\
\hline Viable Autotroph & $1 \mathrm{mg} / \mathrm{L}$ & STOAT Default \\
\hline
\end{tabular}




\begin{tabular}{|l|l|l|}
\hline Viable Heterotroph & $100 \mathrm{mg} / \mathrm{L}$ & STOAT Default \\
\hline
\end{tabular}

Source: Author's Analysis, 2020

For data in Table 5, the default STOAT data is fully used for standard wastewater conditions. This value is used because there were no measurements for the MLSS, Viable Autotroph, and Viable Heterotroph values at the time of sample measurement in the field. The Soluble BOD value itself uses the STOAT default value to assume that it is the BOD value in freshwater used in the Oxidation Ditch unit at the beginning of using a new WWTP.

\subsection{Sensitivity analysis}

Table 6. Sensitivity index value for ischarge

\begin{tabular}{|c|c|c|}
\hline Condition & $\begin{array}{c}\text { Sensitivity } \\
\text { Index TSS }\end{array}$ & $\begin{array}{c}\text { Sensitivity } \\
\text { Index BOD }\end{array}$ \\
\hline $\begin{array}{c}\text { Maximum Discharge } \\
\left(19,023 \mathrm{~m}^{3} / \text { day }\right)\end{array}$ & 17.97 & 23.31 \\
\hline $\begin{array}{c}\text { Minimum Discharge } \\
\left(4,629 \mathrm{~m}^{3} / \text { day }\right)\end{array}$ & 0.92 & 1.1 \\
\hline
\end{tabular}

Source: Author's Analysis, 2020

Table 7. Sensitivity Analysis of TSS

\begin{tabular}{|c|c|c|}
\hline \multirow{2}{*}{ Parameter } & \multicolumn{2}{|c|}{ Sensitivity Analysis } \\
\cline { 2 - 3 } & $\mathbf{+ 5 \%}$ & $\mathbf{+ 5 \%}$ \\
\hline Discharge & 8.4 & 2.67 \\
\hline Sludge Wastage Flow & 1.75 & 3.86 \\
\hline Influent Load & 3.18 & 1.64 \\
\hline MLSS & 1.72 & 1.11 \\
\hline RAS Ratio & 0.8 & 0.75 \\
\hline K $\mathrm{L}$ a Value & 0.01 & 0.01 \\
\hline
\end{tabular}

Source: Author's Analysis, 2020

Table 8. Sensitivity Analysis of BOD 


\begin{tabular}{|c|c|c|}
\hline \multirow{2}{*}{ Parameter } & \multicolumn{2}{|c|}{ Sensitivity Analysis } \\
\cline { 2 - 3 } & $\mathbf{+ 5 \%}$ & $\mathbf{- 5 \%}$ \\
\hline Discharge & 8.88 & 2.86 \\
\hline Sludge Wasteage Flow & 1.36 & 3.42 \\
\hline Influence Load & 3.47 & 1.84 \\
\hline MLSS & 1.39 & 0.8 \\
\hline RAS Ratio & 0.65 & 0.59 \\
\hline KLa Value & 0.01 & 0.01 \\
\hline
\end{tabular}

Source: Author's Analysis, 2020

In addition to using the maximum discharge value and minimum discharge value, the calculation of Sensitivity analysis is also carried out using a value of $+5 \%$ and $-5 \%$ of the original value of each parameter, which besides aims to determine which parameters most influence the quality of wastewater effluent also to determine how much is the WWTP's ability to manage wastewater if there is a change in the parameter value. 1 . Values of $+5 \%$ and $-5 \%$ are used as a comparison to determine the sensitivity fluctuation to changes in the parameters used.

Based on Table 6, it can be seen that the value of the sensitivity analysis obtained when using the maximum and minimum flow fluctuations; based on the data in the table, it can be seen that the maximum discharge is the most sensitive discharge value and affects the quality of the effluent of wastewater. In Table 7 and Table 8 , it can be seen that the most sensitive parameters or the most influencing of effluent quality are the parameters of the discharge of wastewater into the Jababeka 1 WWTP and Sludge Wasteage Flow. Therefore, these two parameters must be considered to ensure the quality of effluent produced by Jababeka 1 WWTP can still meet the specified effluent quality standards. However, because the debit value is difficult for the operator to control, the parameter that also needs to be considered is the MLSS value, where this parameter also still has a sensitivity index value $>1$. The MLSS value itself is still relatively easy for the operator to control. 2. Based on the results of the modeling, it is known that the three parameters that are most sensitive to changes in effluent quality are discharge, sludge wastegate flow, and influent load. These findings show the importance of an equalization tank to ensure the low variability of wastewater discharge and influent load. In addition, the rate of sludge wasteage flow from the Secondary Clarifier and Oxidation Ditch units need to be carefully determined and controlled as slight changes significantly affect the removal efficiency of BOD and TSS.

\subsection{Long-Term Performance}

In addition to simulating several parameters, through the STOAT application, long-term predictions are also made on WWTP's ability to treat wastewater in the next 5 to 10 years. The predicted discharge of wastewater is obtained through a linear equation obtained from wastewater discharge data for Jababeka 1 WWTP throughout 2019, where a linear equation 
of $y=-2.4161 x+13,188$ is obtained (Figure 3 ). The discharge values obtained for the next 5 and 10 years amount to $8,778.8 \mathrm{~m}^{3} /$ day and $4,369.6 \mathrm{~m}^{3} /$ day. Based on the simulation results using STOAT, the effluent values obtained were TSS values $3.71 \mathrm{mg} / \mathrm{L}$ and BOD $0.44 \mathrm{mg} / \mathrm{L}$ for the prediction of the next five years and TSS values of $2.78 \mathrm{mg} / \mathrm{L}$ and BOD $0.3 \mathrm{mg} / \mathrm{L}$ for the prediction of the next ten years.

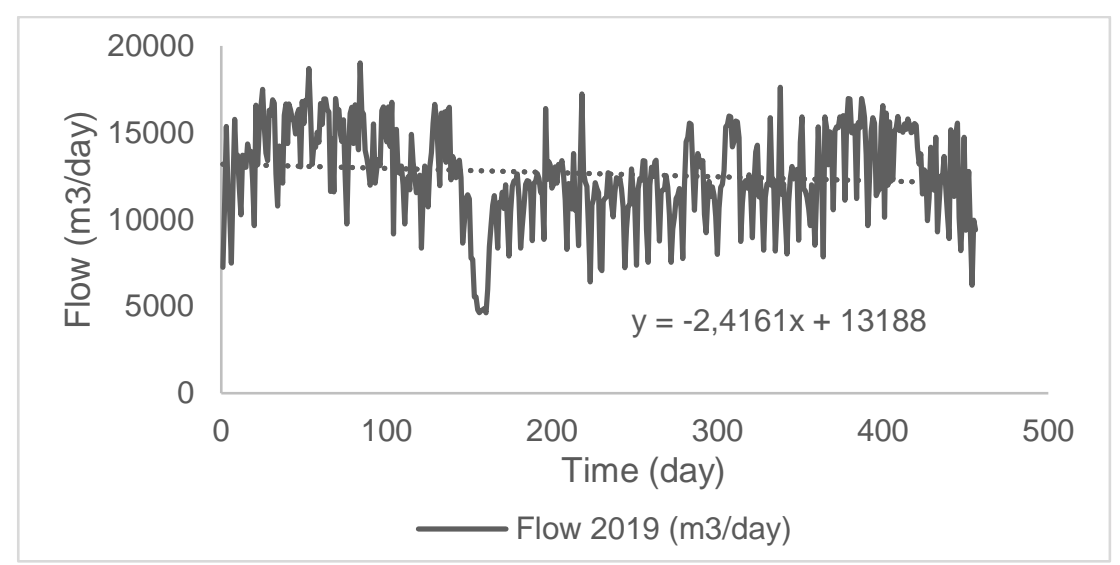

Fig 3. Wastewater Discharge Prediction

Based on the STOAT simulations, it is known that with the current conditions (number of units and unit dimensions), the Jababeka 1 WWTP is still able to treat wastewater with a discharge of 5 years and ten years where the effluent value of the wastewater produced still meets the established quality standards, Regulation of the State Minister for the Environment Number 03 of 2010 concerning Quality Standards for Industrial Estate Wastewater with a TSS effluent value of $150 \mathrm{mg} / \mathrm{L}$ and a BOD effluent of $50 \mathrm{mg} / \mathrm{L}$. This is because the predicted debit for conditions in the next five years and ten years tends to decrease and is still smaller than the maximum discharge for phase 1 of the Jababeka 1 WWTP, which is also a criterion in designing the design of the processing units in the Jababeka 1 WWTP.

\section{Conclusion}

This study aims to evaluate the removal efficiency and the operating parameters of Jababeka 1 WWTP. Based on water sampling, BOD, COD, and TSS removal were $90 \%, 93.02 \%$, and $96.12 \%$, respectively, and have met the effluent standards. Evaluation of operating parameters based on sensitivity analysis has been carried out by STOAT software. The result indicated that WWTP performance was mainly affected by discharge, followed by the influent load, sludge wastage flow, and MLSS. On the contrary, the effect of RAS Ratio and $\mathrm{K}_{\mathrm{L}} \mathrm{a}$ Value was found to be marginal. Based on this finding, Jababeka WWTP operator should focus on a discharge-related parameter in operational, maintenance, and future planning.

\section{Acknowledgements}

This work was funded by Universitas Indonesia through the PUTI Proceedings research grant (contract number: NKB-1109/UN2.RST/HKP.05.00/2020). Technical support from the Laboratory of Sanitation and Environmental Engineering Universitas Indonesia is gratefully 
acknowledged. The authors also wish to thank Mr. Yandes from PT Jababeka for the technical support during the site visit.

\section{References}

1. Badan Pusat Statistik. Statistik Lingkungan Hidup Indonesia 2018. Iriana N, Apriyanto A, Supriyani N, editors. BPS-Statistics Indonesia (2018)

2. Hreiz R, Latifi MA, Roche N, Optimal design and operation of activated sludge processes : State-of-the-art. Chem Eng J [Internet], 281:900, 20 (2015) http://dx.doi.org/10.1016/j.cej.2015.06.125

3. Gao YN, Liu XZ, Zhang RX, Shan JJ, Sun MQ, Zong ZX, et al. Operation and management of Liaoning waste water treatment plants by STOAT Simulation, 04019, 1-4. (2016)

4. Bhave P.P., Naik, S. \& Salunkhe, S.D, Performance Evaluation of Wastewater Treatment Plant. Water Conserv Sci Eng, 5, 23-29 (2020) https://doi.org/10.1007/s41101-020-00081-x

5. STOAT Installation and User Guide.

6. Tarantola S, Saltelli A, Annoni P, Sensitivity analysis , A coming of age. (2009)

7. Chen QS, Xie XH, Du QY, Liu Y, Parameters sensitivity analysis of DO in water quality model of QUAL2K. (2018) DOI: 10.1088/1755-1315/191/1/012030 